\title{
Erratum to: Prioritization strategies for patient evacuations
}

\author{
Ashley Kay Childers ${ }^{1} \cdot$ Maria E. Mayorga ${ }^{1} \cdot$ Kevin M. Taaffe $^{1}$
}

Published online: 26 April 2015

(C) Springer Science+Business Media New York 2015

Erratum to: Health Care Manag Sci (2014) 17:77-87

DOI 10.1007/s10729-013-9236-0

The original version of this article unfortunately contained a mistake. The 10th reference in this article appears as:

10. Bish DR, Acga E, Glick R (2011) Decision support for hospital evacuation and emergency response. Ann Oper Res. doi:10.1007/s10479-011-0943-y.

Last name of the second author erroneously recorded as Acga instead of Agca. The corrected listing of the reference is:

10. Bish DR, Agca E, Glick R (2011) Decision support for hospital evacuation and emergency response. Ann Oper Res. doi:10.1007/s10479-011-0943-y.

The online version of the original article can be found at http://dx.doi.org/ 10.1007/s10729-013-9236-0.

\footnotetext{
Ashley Kay Childers childer@clemson.edu

Maria E. Mayorga

mayorga@clemson.edu

Kevin M. Taaffe

taaffe@clemson.edu

1 Department of Industrial Engineering, Clemson University,

110 Freeman Hall, Clemson, SC 29634-0920, USA
} 